\title{
Co-evolutionary scenarios of intensification and privatization of resource use in rural communities of south-western Niger
}

\author{
R. La Rovere ${ }^{a, *}$, P. Hiernaux ${ }^{b, \dagger}$, H. Van Keulen ${ }^{c}$, \\ J.B. Schiere ${ }^{\mathrm{d}}$, J.A. Szonyi ${ }^{\mathrm{e}}$ \\ a Dept. Protezione e Valorizzazione Agro-alimentare (Di.Pro.Val), Bologna University, Italy \\ b International Livestock Research Institute (ILRI), Niamey, Niger \\ ${ }^{\mathrm{c}}$ Group Plant Production Systems, Wageningen University, Wageningen, The Netherlands \\ d International Agricultural Centre (IAC), Wageningen, The Netherlands \\ e Environmental Economist, Consultant, Aleppo, Syria
}

Received 3 December 2002; received in revised form 26 March 2004; accepted 13 April 2004

\begin{abstract}
Agricultural production in the semi-arid agro-ecosystems of the Sahel centres on cereal staple crops and pastoralism with increasing crop-livestock integration. Animals mobilize soil fertility through manure production, graze crop by-products, and transfer nutrients from distant pastures to cropped areas. Yet in these systems various interacting factors, i.e. climate variability, poor soil fertility, poverty, and institutional constraints limit the capacity of agriculture to keep pace with the growing needs of an increasing human population.

The major trends associated with population growth are (1) increasing area cropped at the expense of rangelands; (2) reduced availability of and access to good quality grazing resources, and (3) seasonal migration of labourers and transhumance of herds. These trends lead to coevolution of farming systems towards increased privatisation of resource use.

This study examines the implications of the development processes where farming systems co-evolve with their surroundings. It explores the impact of integrated management of livestock and crops in rural communities on both the livelihoods of differently endowed farms, and on the agro-ecosystem. Different scenarios explored the co-evolution of three sites situated in Western Niger with their environment. The sites differ in relative area cropped. The scenarios
\end{abstract}

\footnotetext{
${ }^{*}$ Corresponding author. Present address: ICARDA, PO Box 5466, Aleppo, Syrian Arab Republic. Tel.: +963-21-221-3433; fax: +963-21-221-3490.

E-mail address: r.larovere@cgiar.org (R. La Rovere).

${ }^{\dagger}$ Currently at Tropenzentrum, University of Hohenheim (790)n 70593 Stuttgart, Germany.
} 
simulate the different future outcomes for varying socio-economic and biophysical criteria with either current or more intensive management.

Explorative bio-economic models are used to compare a range of farm, livelihood and ecological indicators, and to reveal social and ecological trade-offs.

If current agro-ecosystems and their environments co-evolve towards increased privatisation of grazing resources, then soil fertility is likely to deteriorate on the lands managed by the agro-pastoral groups. Soil fertility may improve on lands managed by the livestock-scarce farmers settled in villages, at the cost of declining farm incomes. The agro-pastoral groups are likely to resort to more distant pastures for feed. The village-based, livestock-endowed farms will resort to feeding on on-farm crop residues. Intensification, though associated with relative decreases in real incomes, will enhance food security in these new systems, except for the poorer settled farmers.

(C) 2004 Elsevier Ltd. All rights reserved.

Keywords: Farming systems co-evolution; Sahel; Crop-livestock integration; Bio-economic modelling; Privatisation; Intensification

\section{Introduction}

Niger ranks among the poorest countries in the world (FAO, 2000). Subsistence farming and pastoralism dominate its rural economy, characterised by low productivity and yield uncertainty. Although $81 \%$ of the country's population lives in rural areas, only $21 \%$ of its GNP originates from the agricultural sector, and $13 \%$ from the livestock sector, which is a major source of exports. Except for mining and tourism, most economic activities of Niger are concentrated in the south which in terms of climate forms part of the Sahel. Since the mid-twentieth century, rapid human population growth has affected agricultural development and the agro-ecosystem of the Sahel in many ways, while the resulting change in resource availability affects farming in a process called co-evolution. Population growth also stimulates development, by forcing technological change (Pearce and Warford, 1993; Boserup, 1983). The livestock population of Niger has increased together with the human population, but at a lower rate (Hiernaux et al., 1998b). As long as enough land is available, the farming communities can meet their increasing food requirements by expansion of cropland and increase in livestock numbers. When suitable land becomes exhausted, crop expansion is forced into marginal areas where either rainfall is too low and unreliable for rain-fed crops, or soils are less fertile and/or more sensitive to erosion, or farming becomes more labour demanding (Schiere et al., 2002). The reduction in fallows and rangeland affects animal production, which is increasingly constrained by quality and/or accessibility of forage. Feed constraints at the end of the dry season and during the cropping season lead to overgrazing of village lands and seasonal transhumance.

Two main forms of livestock production co-exist in Sahelian Niger, pastoralism and mixed crop-livestock farming (Slingerland, 2000). The former is an adaptive strategy that enables livestock holders to subsist by exploiting the better Sahelian and Sudanian rangelands through mobile tracking of resources; hence it provides 
better opportunities for survival than crop farming in drier zones (Thébaud and Batterbury, 2001; Barbier and Hazell, 2000). The latter is based on cereal staple crops, mainly millet intercropped with cowpea, and multi-purpose cattle, sheep and goat husbandry. Their interaction on-farm provides, through the animals' excreta, means by which nutrients are transferred from grazing lands to croplands where the frequency of fallows is no longer sufficient to maintain soil fertility (Turner, 1995), thus allowing the spatial and temporal transfer of nutrients from rangelands and fields with low returns to higher return areas.

The catastrophic losses of livestock suffered by Sahelian pastoralists during the droughts of the 1970s and 1980s forced many of them to take up cropping, while crop farmers, as well as well-off urban citizens, invested in livestock. Thus an increasing number of both crop farmers and pastoralists have become mixed farmers (Slingerland, 2000). Crop residues provide feeds that can maintain livestock during part of the dry season (Savadogo, 2000), while manure from managed animals, passing herds, or corralling contracts between farmers and pastoralists plays a crucial role in soil fertility management for crop land. These mixed farming systems are based on the shared use and management of grazing resources that include open-access rangelands and fallows, as well as post-harvest crop residues. Grazing access is regulated by sophisticated agreements between the owners of the rights to crop the land, livestock managers, and traditional authorities. In these systems, further referred to as 'shared-resource systems', access to grazing resources is, de facto, based on the number of livestock managed. Nutrients and organic matter from manure are shared between area grazed, including croplands when livestock grazes crop residues, and farmland with the excretions of the animals' night resting (Hiernaux et al., 1998a). Systems based on private use of grazing resources, further referred to as 'privatised-resource systems', are spreading in the Sahel. Examples are the development of groundnut cash crops in Senegal and Nigeria; reserved use of sorghum residues in Northern Nigeria; ranching pastures in Mauritania and Chad (Sissoko, 1998; Savadogo, 2000; Slingerland, 2000; Mortimore and Adams, 2001), promoted by increasing pressure on resources and enabled by improved access to markets and favourable socio-political environment (De Ridder et al., 2004; Raynaut, 2001).

The relative area cropped, the ratio of area cropped to total arable area, increases at the expense of fallows and rangelands, and provides an indication of the relative presence of fallows. It differs from intensification, which involves higher use of productive inputs per unit area cropped, in a variety of different combinations and degrees of intensity: labour, fertiliser, soil conservation measures, and crop residue management (Powell et al., 1996).

Following definition of the major challenges in the study area, two questions arise on the co-evolution of these systems and their environment:

(1) How would the present farming systems change under increased privatisation of use of common pooled resources, especially the grazing resources?

(2) What impact will more intensive forms of management have on farmers' options, production, and livelihoods, and for agro-ecosystem health?

The large variability in farming systems and environments makes it impossible to give single answers to these questions, and entails a degree of complexity that 
requires a systems approach. Sahelian farming systems are a case in point for the need of such approaches (Breman and De Wit, 1983). This paper employs and integrates elements from 'hard', 'soft', and 'complex' system thinking (Schiere et al., in press). While 'hard' systems approaches look mainly at biophysical aspects, and 'soft' systems approaches look at aspects of social organizations and cultural change, complex systems approaches stress the effects and changes due to interactions between systems, and between systems and their environment. The co-evolution and nutrient dynamics described in this paper are examples of interactions between change in systems and their contexts (Norgaard, 1984; Schiere et al., 2002). Complexity and mode-changes also are at the heart of the evolutionary processes between farming systems and their social, institutional, and policy environments, as described in relation to intensification and population pressure by Boserup (1983) and intensification and induced technological change by Ruttan and Hayami (1985).

\section{Materials and methods}

The study area is located north of the capital Niamey in Dantiandou administrative district, Département of Tillabéry, in south-western Niger, between the valleys of the Niger River to the west and the Dallol Bosso to the east. Three contiguous sites in the area - henceforth identified by the name of their largest villages: Banizoumbou, Tigo Tegui, and Kodey, respectively - share the same tropical semi-arid climate with $450 \mathrm{~mm}$ annual rainfall on average in a single rainy season (June-September) - same geology, geomorphology, and soils from the same low sandstone plateau. The sites have similar access to the Dantiandou market, where they trade the same agricultural commodities. They differ however in terms of the relative area cropped, as a result of their settlement and land use history, and by the density of human and livestock populations (Hiernaux et al., 1998b). The Djerma, originating from upstream Niger, shifted progressively south to the region where the study area is situated. Their settlement was relatively independent of available land resources, as it was governed by access to surface water or wells, or by the possibility to dig new wells around which seasonal cropping communities may become permanent. Population in the region is increasing at a steady 3.4\% (FAO, 2000), a trend projected to continue over the next two decades, accompanied by urbanisation and emigration. In the area, livestock population and density are increasing concurrently with the human population, though at slightly lower rates (Hiernaux et al., 1998b).

\subsection{The modelling approach}

The impact on farm performance and agro-ecosystem functions of the privatization of the use of common resources and of the adoption of more intensive management was examined through a methodology (Fig. 1) that integrates socio-economic and biophysical databases and tools for data generation and management, with a bio-economic model. This model (Fig. 2) uses a modified farm household level model (Sissoko, 1998; Kruseman, 2000), based on linear programming, aimed at quantify- 


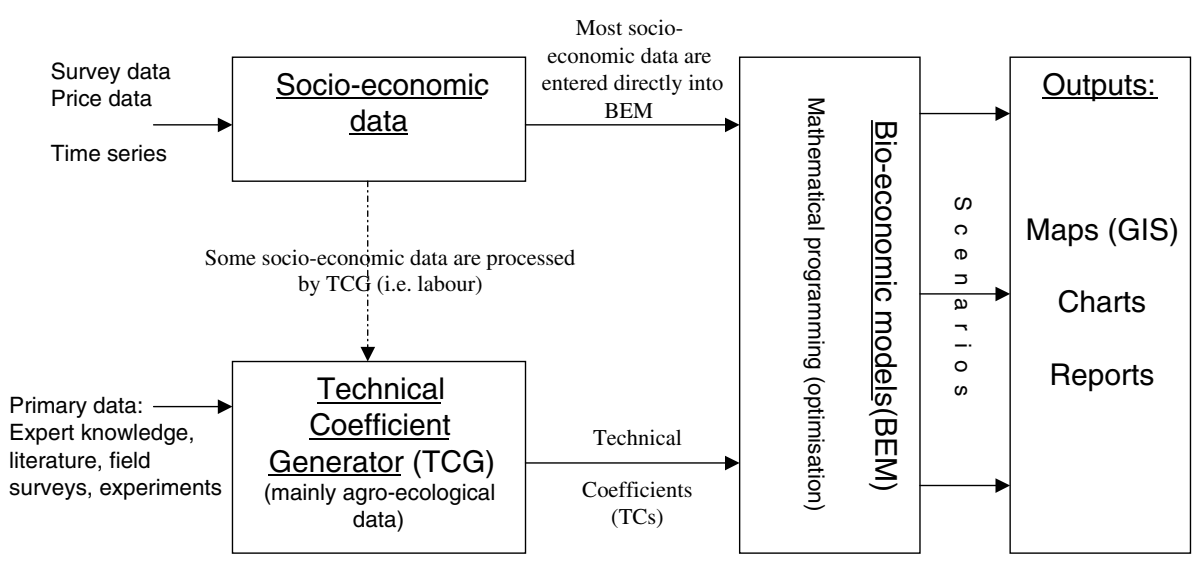

Fig. 1. General framework of methodology and materials.

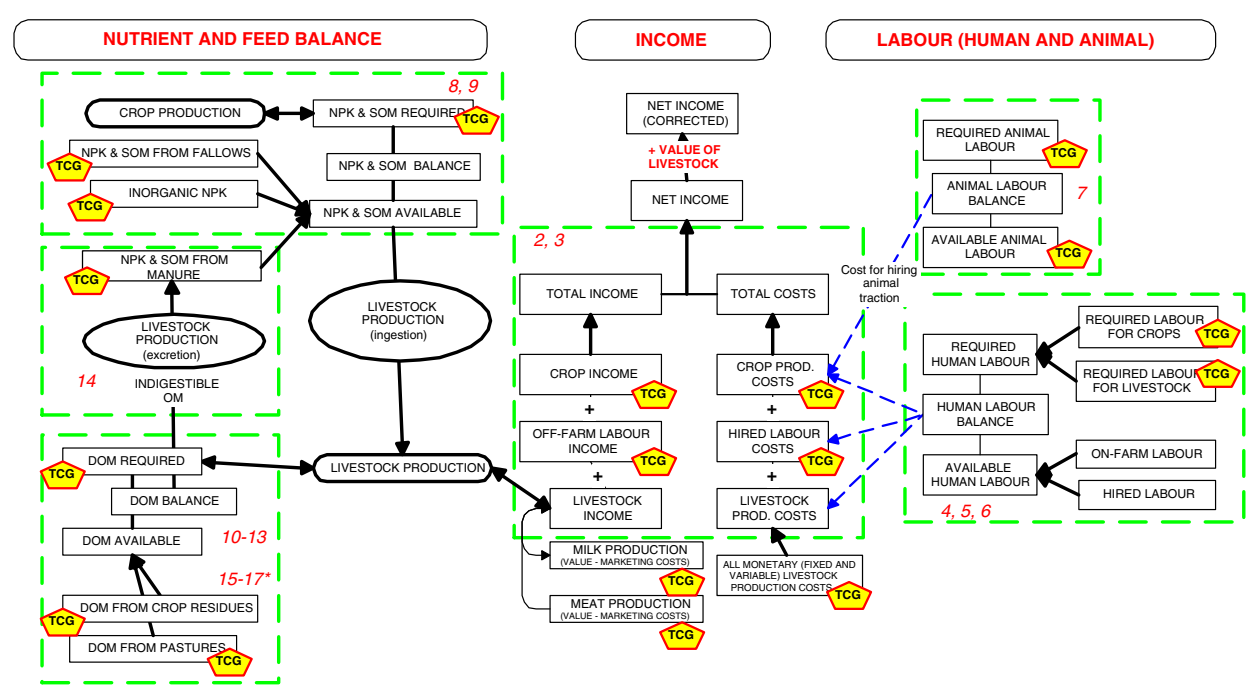

Fig. 2. Structure of selected parts of the modelling system.

ing and comparing farm household performance and agro-ecological indicators (production, consumption, soil fertility, income, human and animal labour, feed availability, and land use changes) by means of scenario analyses. Geo-referenced inputs were used to generate spatially explicit scenario outputs suitable for GIS visualization, aimed at relating livestock-mediated soil fertility dynamics to different soil and farm types. Although the model mostly addresses the farm household level, adhoc routines were developed to aggregate specific resources (land, labour, forage) at the community level, to take into account limited community resources, and to avoid the possibility that these might be trespassed in the scenarios. To account for the 
open access grazing resources within villages and for herd mobility, an algorithm was developed to calculate livestock intake and excretions outside farm boundaries.

The questions of management intensification and/or resource privatization were addressed through explorative scenarios aimed at answering 'what-if'-questions with respect to the likely co-evolutionary pathways of local farming systems with their environment. The system's co-evolution can be imagined as a shift from the relatively extensive land uses of site Banizoumbou to the more intensive ones of site Kodey. Privatization consists of a change from current conditions - with communally managed open access resources - to likely futures characterized by increasingly privatised grazing resources. This may involve a shift to:

- First, restricted use of crop residues. This does not require changed land tenure systems, but private harvesting and stocking of residues.

- Second, restricted use of fallows. This requires an extension of existing inherited rights - that allow cropping the land and future harvest of crop residues - to a situation at which there is private use of resources from the land when converted to fallow.

- Third, possibly in the longer term, restricted use of non-arable rangelands. This will require the creation of new tenure rights to accommodate group or individual ranching.

Current and more intensive, locally feasible modes of production were defined in such a way as to simulate the combined adoption of crop and livestock management options. They include, within the integration on-farm of crops and animals, alternative crop residue management, labour input, use of mineral fertilisers or manure, either collected in corrals/paddocks, transported and applied manually to the field, or deposited on the fields by corralled animals, different lengths of fallows which influence the relative area cropped within farmlands, and various soil conservation measures.

\subsection{The farm household database}

The extensive farm database was developed between 1994 and 2000 in the framework of a research project on crop-livestock interactions in semi-arid zones of West Africa, by scientists from the International Livestock Research Institute (ILRI) in collaboration with the National Research Institute of Agriculture in Niger (INRAN) and the International Crops Research Institute for the Semi-Arid Tropics (ICRISAT). That database included information on the composition and activities of households (selected data are given in Table 1), on farm assets, land rights and management, livestock owned and managed, and equipment, documented for 542 farms from the three neighbouring sites (Powell et al., 1996; Hiernaux et al., 1998a,b; Turner and Hiernaux, 2002). The database also includes spatial information on land tenure, land use, crop yields, seasonal vegetation mass and composition, and herd grazing itineraries over the three sites covering a total area of about $500 \mathrm{~km}^{2}$. Primary data and statistics derived from the database are included in the model, either directly or after transformation into technical coefficients (TCs), which are required to quantify agricultural activities and agro-ecological processes. This transformation 
Table 1

Farm household typology and agro-economic information

\begin{tabular}{|c|c|c|c|c|c|c|c|}
\hline \multicolumn{3}{|c|}{ Farm (Household) type } & \multicolumn{2}{|l|}{ Camp } & \multicolumn{3}{|l|}{ Village } \\
\hline & & & Poor & Rich & Managers & Poor & Rich \\
\hline \multirow[t]{4}{*}{ Sample size: } & Bani & & 33 & 14 & 13 & 110 & 46 \\
\hline & Tigo & & 25 & 31 & 11 & 62 & 65 \\
\hline & Kodey & & 34 & 29 & 3 & 41 & 15 \\
\hline & (Total) & & 92 & 74 & 27 & 213 & 126 \\
\hline \multicolumn{3}{|l|}{ Average family size } & 9.60 & 9.59 & 15.59 & 8.79 & 8.27 \\
\hline \multicolumn{2}{|l|}{ Labour availability } & Aleq $^{a}$ & 5.84 & 5.43 & 8.38 & 4.94 & 4.53 \\
\hline \multirow[t]{4}{*}{ Livestock: } & Cattle & $\mathrm{TLU}^{\mathrm{b}}$ & 3.12 & 10.8 & 8.89 & 0.75 & 0.51 \\
\hline & Goats & TLU & 0.95 & 1.80 & 0.33 & 0.11 & 0.08 \\
\hline & Sheep & TLU & 0.46 & 1.31 & 0.51 & 0.10 & 0.11 \\
\hline & Total & & 5.54 & 15.48 & 11.2 & 1.37 & 0.96 \\
\hline \multicolumn{2}{|c|}{ Average transhumant animals } & TLU & 2.5 & 7 & 1.2 & 0.14 & 0.10 \\
\hline \multirow[t]{2}{*}{ Traction: } & $\begin{array}{l}\text { Oxen, } \\
\text { donkeys }\end{array}$ & (head) & 2.49 & 3.53 & 2.25 & 0.58 & 0.47 \\
\hline & Carts & $\#$ & 0.04 & 0.03 & 0.56 & 0.00 & 0.00 \\
\hline \multicolumn{2}{|l|}{ Land availability } & (ha) & 8.71 & 12.66 & 25.24 & 9.06 & 21.38 \\
\hline \multicolumn{2}{|l|}{ Cropland per adult } & ha/aceq ${ }^{\mathrm{c}}$ & 1.3 & 2.3 & 2.5 & 1.6 & 4.3 \\
\hline \multicolumn{2}{|l|}{ Cropland per TLU } & ha/TLU & 1.57 & 0.81 & 2.13 & 6.61 & 22.27 \\
\hline \multicolumn{3}{|c|}{$\begin{array}{l}\delta \text {-factor of grazing resource use } \\
\text { proportionality to managed animals }\end{array}$} & 1.84 & 3.55 & 1.31 & 0.44 & 0.13 \\
\hline
\end{tabular}

${ }^{a}$ Adult labour equivalent.

${ }^{\mathrm{b}}$ TLU is Tropical Livestock Unit, a hypothetical animal of $250 \mathrm{~kg}$ live weight. Used to bring different animal species under a common denominator.

${ }^{\mathrm{c}}$ Adult consumer equivalent.

${ }^{\mathrm{d}}$ See text for explanation.

was operationalised through an external technical coefficient generator (TCG), fed with on-farm and on-station experimental data on crop and livestock production and with complementary survey data from local research and government institutions. TCGs integrate and synthesize different databases and models or their results, and enable quantification of cropping systems in a transparent and reproducible way. Using intelligent interfaces, relevant inputs and outputs of engineered cropping systems characterized by their design criteria can be jointly calculated and analyzed (Hengsdijk and Van Ittersum, 2003). The TCG used in this study (for details, refer to Hengsdijk et al., 1996) was adapted from an integrated framework for analysing sustainable land use, developed by a Dutch-West African research project.

\subsection{Scenarios modelled}

The system is explored at given points in time to identify differences in farm performance and resource use at various levels of relative area cropped and intensification. The two are associated, yet are not synonymous nor directly related, though the latter may be partially triggered by the former. The spatial variability in the relative area cropped in the study region ranges from low $(<25 \%)$ to high $(>90 \%)$, which 
Table 2

Qualitative characteristics of different levels of cropping management intensification

\begin{tabular}{|c|c|c|c|c|c|}
\hline & Fallows & Manure use & Tillage & Fertilizer use & $\begin{array}{l}\text { Draught } \\
\text { power use }\end{array}$ \\
\hline \multicolumn{6}{|c|}{ Current management options } \\
\hline Very extensive & Long & - & - & - & - \\
\hline Extensive & Long/Short & - & - & - & Very low \\
\hline Semi-intensive & Short/none & Limited & Low & Low & Very low \\
\hline \multicolumn{6}{|c|}{ More intensive management options } \\
\hline Semi-intensive & Short/none & Limited & Low & Low & Low \\
\hline Intensive & Short/none & Limited & Plain & Low & Low \\
\hline Very Intensive & - & Intensive & Ridging & Significant & Significant \\
\hline
\end{tabular}

includes the relative area cropped at three sites of the area: Bani $(40 \%)$, Tigo $(50 \%)$, and Kodey $(65 \%)$. The levels of intensification, referring to cropping systems, are qualitatively defined in terms of combinations of inputs (manure, labour, fertilizer, draught power use) and length of fallow (Table 2).

The socio-economic and land use survey database components developed by ILRI, bibliographical sources, and local and ILRI expert knowledge were used to characterize farm types (henceforth 'farms'). In each of the three sites the survey covered the local communities of mostly Djerma crop farmers, settled in villages, and the Fulani agro-pastoralists, settled in scattered camps. Both groups live in the same agro-ecosystem, but have different means of production, access rights to resources, and production objectives. The Fulani inherited from their pastoralist tradition the husbandry skills, the seasonal herd transhumance, and the livestock capital. They, however, have become increasingly more sedentary. They now live in 'camps', situated around the predominantly Djerma villages, on which they depend for water. These camps are scattered and far apart to avoid mixing of herds, and located in the proximity of livestock paths to allow animal access to the camp during the growing season. They are progressively shifting to cropping, although they have no rights over the land, which they access through 'manure-for-grazing' contracts with the village farmers (Slingerland, 2000). Most of the village farmers, by contrast, hold traditional rights over the land, but own fewer animals. Some of the larger households, however, do own substantial livestock capital, in addition to being heavily engaged in cropping. Based on the type of settlement, on the endowment in cropland and livestock managed (access to cropland, herd size/composition, human and animal labour), five farms were stratified (Table 1). The farm typology comprises:

- fairly well livestock-endowed but land-scarce 'camp poor',

- well livestock-endowed 'camp rich',

- land-endowed village farmers which also manage herds (village managers),

- livestock-scarce and land-scarce 'village poor',

- land-endowed but livestock-scarce 'village rich'. 


\subsection{Model assumptions and definitions}

In the model, fallow is considered to have two functions, a land use part of the crop rotation system managed within the farm, and a source of animal feed managed communally. The agronomic rationale behind this derives from the need for replenishment of organic matter and nutrients during the fallow period, and the provision of grazing resources.

It is generally accepted (Penning de Vries and Djitèye, 1991; Breman and De Wit, 1983) that in the Sahel, while locally crop growth may be driven by soil moisture availability, productivity is limited by soil nitrogen $(\mathrm{N})$ and phosphorus $(\mathrm{P})$ availability, in part related to rainfall and to topsoil clay and organic matter content. The topsoil fertility status was assessed per soil type within the farm, depending on management, as the difference between availability in soil and crop requirements for soil organic matter (SOM), P and N. Four typical soil types were defined on the basis of their features and agronomic suitability.

The pasture area accessible to farm animals was calculated (within the limits of available pastureland) by assuming that pasture area used was proportional to the number of livestock managed at specific times of the year. This proportionality is made operational through a farm type-specific $\delta$ coefficient (Table 1) calculated from data on land, livestock and pastures, aggregated over the total number of farms within a site. In calculating $\delta$, total availability and use of crop residues is taken into account, and it allows considering the possibility of using common-pool feed resources and/or crop residues in proportion to the herd size (expressed in Tropical Livestock Units, TLUs ${ }^{1}$ ) managed, and in relation to the number of TLUs managed by other farm types. For instance, a $\delta$ of 1.84 for 'camp poor' farms means that they have access to $84 \%$ more land and feed than they own. Stocking rates were derived from community aggregate animal numbers and grazing land available. This parameter is at the basis of scenarios that simulate privatization; its presence in the models refers to a situation with shared use of grazing resources, its absence refers to privatization.

Total digestible organic matter (DOM) annually required by a tropical livestock unit (TLU) was calculated at $1100 \mathrm{~kg}$, based on an estimated maximum of $2300 \mathrm{~kg}$ Dry Matter [DM] intake, and a value for DM digestibility of $40-55 \%$ (Hengsdijk et al., 1996). If feed availability fell below this threshold, then quality feed available on-site for the livestock of a given farm was probably becoming scarce. This might be a trigger for the herder's reactive decision to move the animals through transhumance to areas with higher feed availability. Decisions on herd transhumance are in fact proactive, rather than reactive (Schlecht et al., 2001; Turner, 1995). Herds are moved to use forages and fallows in the relatively near southern and wetter areas of the Sahel at the end of the dry season when local crop residues from the previous year are becoming scarce, pastures in the Northern Sahel during the wet season, and crop residues from the nearby village lands just after the harvest is completed.

\footnotetext{
${ }^{1}$ Customarily defined as a hypothetical animal of $250 \mathrm{~kg}$ live weight.
} 
In terms of food security, annual (human) consumption requirements of grain were assumed to be: $200 \mathrm{~kg} /$ adult equivalent for nomads, $250 \mathrm{~kg} /$ adult equivalent for settled rural people (AP3A Project, 2001). This estimate acknowledges the increased demand when religious and traditional events take place. For nutritional reasons, part of the food requirements is assumed to come from meat $(18.25 \mathrm{~kg})$ and milk $(49 \mathrm{~kg})$ (CIPEA/ILCA, 1994). Farm income, based on survey data, consists of net income from sales of crops, livestock, animal products, and off-farm labour. Annual minimum income estimated to be sufficient for subsistence ( 90000 CFA p.c.) is a proxy for total monetary value of the nutritional requirements per adult equivalent at market prices, plus a premium to cover expenses to meet social obligations.

\subsection{Key equations}

The model (Table 3 and Appendix A) maximizes an inter-temporal utility function (Eq. (1)) to compare the performance of different farm types at different levels of relative area cropped and intensification. It optimises the weighted sum of food and income security, in which the 'food security' objective is assumed to be of higher priority $\left(\Phi_{1}\right)$ and the 'income' objective of lower priority $\left(\Phi_{2}\right)$. The utility curve is provided exogenously (cf. Sissoko, 1998; Kruseman, 2000). Total income (Eq. (2)) equals the value of crop and animal production sales and off-farm labour earnings, minus the costs incurred by the household. The cost of production includes the total cost of crop and animal production and the cost of hired labour. Corrected income (Eq. (3)) equals net income plus the value of owned livestock.

Eqs. (4)-(6) describe the labour balance for the farm household, and animal traction (Eq. (7)) performed by oxen and donkeys for cropping.

Aggregate nutrient balance (soil fertility status) (Eq. (8)) is calculated as the difference between available and required nutrients for crop growth and organic matter mineralization. Total available nutrients and organic matter from manure (Eq. (9)) are assumed proportional to the number of farm animals and average time spent in resting areas, along trails, around water sources, and grazing. The organic matter recycled by livestock through faecal excretion was calculated from the fraction of indigestible organic matter (Schlecht et al., 2004). To account for the alternative management of livestock excretions, the nutrients and organic matter (Eq. (9)) from animal excretions were split:

- The excreta (faeces and urine) produced by animals during night confinement $(50 \%)$ either corralled on a field or in the farmyard, are managed within the farm and available to be applied on-farm. These excretions are produced by the managed animals, in a quantity proportional to farm livestock density, as operationalised in the farm-specific $\delta$ factor.

- The remaining half of the organic matter and nutrients is excreted by the animals along the grazing itineraries, irrespective of farmland boundaries (Turner and Hiernaux, 2002). It has been observed that the excretion deposited during grazing is proportional to the time spent grazing and the number of animals (Schlecht et al., 2004), which is approximated by total feed availability on the plot. Of these flows, only the part proportional to the land managed will return to the farm. 
Table 3

Selected key equations of the model (see Appendix A for explanation of parameter and variable names)

Objective function (from utility of consumption and corrected income)

$\mathrm{UTIL}=\left(\Phi_{1} /\right.$ maxconut $) * \mathrm{UCO}+\left(\Phi_{2} /\right.$ maxcorin $) *$ CORINC $)$

Net income (revenue minus production costs)

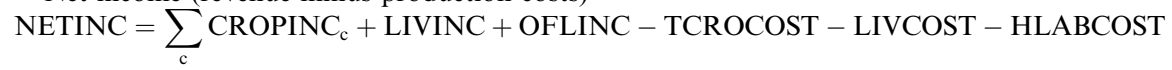

Corrected income (net income plus value of owned animals)

$\mathrm{CORINC}=\mathrm{NETINC}+\sum_{\mathrm{t}, \mathrm{r}} \operatorname{pan}_{\mathrm{t}, \mathrm{r}} * \mathrm{NANIMAL} \mathrm{t}_{\mathrm{t}, \mathrm{r}}+$ pdonk $*$ LABDONK + poxen $*$ LABOXEN

Labour balance per period (labour availability minus requirement)

$\mathrm{LABBAL}_{\mathrm{p}}=\mathrm{TLABAVA}_{\mathrm{p}}-\mathrm{TLABREQ}_{\mathrm{p}}$

Total labour availability (family labour minus off-farm labour plus hired labour)

TLABAVA $_{\mathrm{p}}<$ famlab $_{\mathrm{p}}-\mathrm{OFL}_{\mathrm{p}}+\mathrm{HIRLAB}_{\mathrm{p}}$

Total labour requirement (crop labour requirements plus herding labour requirements)

TLABREQ $_{\mathrm{p}}>\sum_{\mathrm{c}, \mathrm{s}, \mathrm{a}}$ labcrreq $_{\mathrm{p}, \mathrm{c}, \mathrm{s}, \mathrm{a}} *$ LANDUSE $_{\mathrm{c}, \mathrm{s}, \mathrm{a}}+\sum_{\mathrm{t}, \mathrm{r}}$ labanreq $_{\mathrm{p}, \mathrm{t}, \mathrm{r}} * \mathrm{NANIMAL}_{\mathrm{t}, \mathrm{r}}$

Animal labour balance (requirement and availability)

TRAC $_{\mathrm{k}}=\sum_{\mathrm{c}, \mathrm{s}, \mathrm{a}}$ anlabreq $_{\mathrm{k}, \mathrm{c}, \mathrm{s}, \mathrm{a}} *$ LANDUSE $_{\mathrm{c}, \mathrm{s}, \mathrm{a}}-$ anlabav $_{\mathrm{k}}$

Nutrient and Soil Organic Matter balance (availability and requirement)

NUTBAL $_{\mathrm{s}, \mathrm{f}}=\mathrm{NUTAVA}_{\mathrm{s}, \mathrm{f}}+\sum_{\mathrm{ct}, \mathrm{a}}$ resnutreq $_{\mathrm{ct}, \mathrm{s}, \mathrm{a}, \mathrm{f}} * \mathrm{LANDUSE}_{\mathrm{ct}, \mathrm{s}, \mathrm{a}}$

Nutrient and SOM availability

$$
\begin{aligned}
& \text { NUTAVA }_{\mathrm{s}, \mathrm{f}}=\delta * 0.5 *\left(\sum_{\mathrm{ct}, \mathrm{a}} \text { fertava }_{\mathrm{ct}, \mathrm{s}, \mathrm{a}, \mathrm{f}} * \operatorname{LANDUSE}_{\mathrm{ct}, \mathrm{s}, \mathrm{a}}+\sum_{\mathrm{c}, \mathrm{a}} \text { falnutava }_{{ }_{\mathrm{fa}} \mathrm{f}^{\prime}, \mathrm{s}, \mathrm{a}, \mathrm{f}} * \text { LANDUSE }_{\mathrm{fa}^{\prime}, \mathrm{s}, \mathrm{a}}\right) \\
& +0.5 *\left(\sum_{\mathrm{ct}, \mathrm{a}} \text { fertava }_{\mathrm{ct}, \mathrm{s}, \mathrm{a}, \mathrm{f}} * \operatorname{LANDUSE}_{\mathrm{mmi}^{\prime}, \mathrm{s}, \mathrm{a}}+\sum_{\mathrm{c}, \mathrm{a}} \text { falnutava }_{\mathrm{fa}^{\prime}, \mathrm{s}, \mathrm{a}, \mathrm{f}} * \operatorname{LANDUSE}_{\mathrm{fa}^{\prime}, \mathrm{s}, \mathrm{a}}\right)
\end{aligned}
$$

Digestible organic matter (DOM) balance (availability and requirement)

DOMBAL $_{\mathrm{q}}=$ DOMAVA $_{\mathrm{q}}-\sum_{\mathrm{m}, \mathrm{r}}$ tdomreq $_{\mathrm{q}, \mathrm{m}, \mathrm{r}} *$ DOMREQ $_{\mathrm{m}, \mathrm{r}}$

Total digestible organic matter availability (residues and pastures)

DOMAVA $_{\mathrm{q}}=$ TOTRES $_{\mathrm{q}}+\sum_{\mathrm{e}, \mathrm{s}}$ pastyield $_{\mathrm{e}, \mathrm{s}, \mathrm{q}} *$ PASTAVA $_{\mathrm{e}, \mathrm{s}}$

Crop residue availability (production)

$$
\begin{aligned}
& \text { TOTRES }_{\mathrm{q}}=\alpha * \delta * \sum_{\mathrm{s}, \mathrm{a}} \operatorname{cropresy}_{\mathrm{q},{ }^{\prime} \mathrm{mi}^{\prime}, \mathrm{s}, \mathrm{a}} * \operatorname{LANDUSE}_{\mathrm{mi}^{\prime}, \mathrm{s}, \mathrm{a}}+(1-\alpha) * \sum_{s, a} \operatorname{cropresy}_{\mathrm{q},{ }^{\prime} \mathrm{mi}^{\prime}, \mathrm{s}, \mathrm{a}} \\
& * \text { LANDUSE }_{\mathrm{cmi}^{\prime}, \mathrm{s}, \mathrm{a}}+(1-\mathrm{Tr}) \sum_{\mathrm{s}, \mathrm{a}} \operatorname{cropresy}_{\mathrm{q},{ }^{\prime} \mathrm{so}^{\prime}, \mathrm{s}, \mathrm{a}} \text { LANDUSE }_{\mathrm{so}^{\prime}, \mathrm{s}, \mathrm{a}}+(1-\mathrm{Tr}) \\
& \times \sum_{\mathrm{s}, \mathrm{a}} \operatorname{cropresy}_{\mathrm{q},{ }^{\prime} \mathrm{ni}^{\prime}, \mathrm{s}, \mathrm{a}} \text { LANDUSE }_{\mathrm{ni}{ }^{\prime}, \mathrm{s}, \mathrm{a}}
\end{aligned}
$$

Digestible organic matter (DOM) requirement

$$
\begin{aligned}
& \sum_{\mathrm{m}} \text { DOMREQ }_{\mathrm{m}, \mathrm{r}}>\sum_{\mathrm{t}}\left[\text { domreqan }_{\mathrm{cca}^{\prime}, \mathrm{r}} *\left(\mathrm{NANIMAL}_{\mathrm{cca}^{\prime}, \mathrm{r}}+\mathrm{LABOXEN}-\left(T_{\mathrm{S}}+T_{\mathrm{L}}\right) * \operatorname{translvy}_{{ }^{\prime} \mathrm{ca}^{\prime}}\right)\right] \\
& + \text { domreqan }_{{ }^{\prime} \mathrm{sh}^{\prime}, \mathrm{r}} * \mathrm{NANIMAL}_{{ }_{\mathrm{sh}}{ }^{\prime}, \mathrm{r}}+\text { domreqan }_{{ }_{\mathrm{goo}}, \mathrm{r}} * \mathrm{NANIMAL}_{\mathrm{go}^{\prime}, \mathrm{r}}
\end{aligned}
$$


Table 3 (continued)

Manure production from the animals

MANURE $_{\mathrm{OM}^{\prime}}=\sum_{\mathrm{m}, \mathrm{r}}$ indigom $_{\mathrm{m}, \mathrm{r}} *$ DOMREQ $_{\mathrm{m}, \mathrm{r}}$

DOM balance during transhumance time

DOMBATRAN $=\sum_{\mathrm{bq}}$ DOMAVTRA $_{\mathrm{bq}}-\left(T_{\mathrm{S}}+T_{\mathrm{L}}\right) * \sum_{\mathrm{m}, \mathrm{r}}$ tdomreq $_{\mathrm{q}, \mathrm{m}, \mathrm{r}} *$ DOMREQ $_{\mathrm{m}, \mathrm{r}}$

DOM availability in transhumance (pastures for wet season, for all year, and residues available during transhumance time)

$$
\begin{aligned}
\text { DOMAVTRA }_{\mathrm{bq}}= & \sum_{\mathrm{e}, \mathrm{s}} \text { pastyield }_{\mathrm{w}^{\prime}, \mathrm{s}, \mathrm{bq}} * \text { PASTAVA }_{\mathrm{c}^{\prime}, \mathrm{s}}+T_{\mathrm{S}} * \sum_{\mathrm{e}, \mathrm{s}} \text { pastyield }_{\mathrm{c}^{\prime}, \mathrm{s}, \mathrm{bq}} * \text { PASTAVA }_{\mathrm{y}^{\prime}, \mathrm{s}} \\
& +\sum_{\mathrm{ct}} \text { RESCRTRA }_{\mathrm{bq}, \mathrm{ct}}
\end{aligned}
$$

Total crop residue production during transhumance

$$
\begin{aligned}
& \sum_{\mathrm{ct}} \operatorname{RESCRTRA}_{\mathrm{bq}, \mathrm{ct}}=\alpha * T_{\mathrm{S}} * \delta * \sum_{\mathrm{s}, \mathrm{a}} \operatorname{cropresy}_{\mathrm{bq}^{\prime}{ }^{\prime} \mathrm{mi}^{\prime}, \mathrm{s}, \mathrm{a}} * \operatorname{LANDUSE}_{{ }_{\mathrm{mil}}{ }^{\prime}, \mathrm{s}, \mathrm{a}}+(1-\alpha) * T_{\mathrm{L}} \\
& * \sum_{\mathrm{s}, \mathrm{a}} \operatorname{cropresy}_{\mathrm{bq},{ }^{\prime} \mathrm{mi}^{\prime}, \mathrm{s}, \mathrm{a}} * \operatorname{LANDUSE}_{{ }_{\mathrm{mi}}{ }^{\prime}, \mathrm{s}, \mathrm{a}}+T_{\mathrm{L}} * \sum_{\mathrm{s}, \mathrm{a}} \operatorname{cropresy}_{\mathrm{bq},{ }^{\prime} \mathrm{so}^{\prime}, \mathrm{s}, \mathrm{a}} \\
& * \text { LANDUSE'so' }^{\prime}, \mathrm{s}, \mathrm{a}+T_{\mathrm{L}} * \sum_{\mathrm{s}, \mathrm{a}} \text { cropresy }_{\mathrm{bq},{ }^{\prime} \mathrm{ni}^{\prime}, \mathrm{s}, \mathrm{a}} * \mathrm{LANDUSE}_{{ }_{\mathrm{nni}}{ }^{\prime}, \mathrm{s}, \mathrm{a}}
\end{aligned}
$$

Total available macronutrient balances also include the customary amount of mineral fertilizers applied at each level of intensification (qualitatively indicated in Table 2).

The aggregate balance of digestible organic matter (DOM) (Eq. (10)) is given by DOM availability minus requirements. The amount of DOM (Eq. (11)) available for grazing by livestock of the different farms comprises the fraction of the crop residues left in the field, fallow forages, and rangeland pastures. The fallow area for each farm type is set by adjusting the farms' land use patterns to the aggregated available fallow area. Pasture availability (generated externally to the model by means of the TCG system) varies in dependence of season and the related type and quality of forage.

In the model, the non-harvested fraction of crop residues (mostly $80 \%$ of millet stalks) is referred to as $[\alpha]$, the harvested residues (about $20 \%$ of millet stalks, part of sorghum stalks, and all cowpea haulms) thus represent $[1-\alpha]$. The period preceding cropping, when fields are still accessible to animals and when short transhumance may take place to benefit from southern pastures is $\left[T_{\mathrm{S}}\right]$, the wet season when cropping takes place, fields are inaccessible to animals, and part of the herds goes on long transhumance to benefit from Northern pastures is $\left[T_{\mathrm{L}}\right]$. Following harvest, animals can access again the residues of the recently harvested crops during the initial part of the dry season $\left[T_{\mathrm{R}}\right]$ when millet residues left in the field can be exploited through local mobility of herds.

The $[1-\alpha]$ fraction of harvested residues is assumed to be consumed on-farm by the farm animals during the whole year until they are finished, except during $T_{\mathrm{R}}$, when the $[\alpha]$ fraction of mostly millet residues is grazed in the fields. This is considered to be an open-access resource (Eq. (12)), grazed proportionally $[\delta]$ to the size of 
passing herds. The organic matter of $[\alpha]$ is returned to the soil (along grazing trails or in corrals), and of $[1-\alpha]$ is mobilized with the harvested crop residues. Grazing and decomposition of fallow and rangeland forage are modelled according to similar principles.

The DOM required for feeding the animals, assumed proportional to farm herd size, is composed of a combination of available feed rations and energy intake levels specific for each of the animal species (Eq. (13)). Its calculation discounts those animals (mainly cattle) that leave on transhumance [translvy] for the average time when they are away $\left(T_{\mathrm{S}}+T_{\mathrm{L}}\right)$.

Total annual manure production (Eq. (14)) is proportional to number of farm animals. A fraction of the indigestible organic matter present in animal diets is excreted in faeces [indigom].

The balance of DOM (Eq. (15)) during the full transhumance period $\left(T_{\mathrm{S}}+T_{\mathrm{L}}\right)$ is total DOM available, composed mostly of better quality forages available during the wet season from the northern pastures, minus the DOM required. This balance, however, does not take into account the DOM requirements of the animals on transhumance.

The access to pastures of the type available year-round [PASTAVA ${ }_{y^{\prime}{ }^{\prime}}$ ], during the short transhumance time that precedes cropping $\left[T_{\mathrm{S}}\right]$ and to the pastures of better quality available $\left[\right.$ PASTAVA $\left._{{ }^{\prime}{ }^{\prime} \mathrm{s}}\right]$ during the wet season $\left[T_{\mathrm{L}}\right]$, is also proportional to livestock numbers (Eq. (16)).

Crop residues [RESCRTRA $A_{b q}$ ] of better quality available for feeding the animals that remain on-site during the time of transhumance (Eq. (17)) consist of millet residues left in the field after the previous year's harvest and consumed during the time that precedes the cropping season when fields are still accessible $\left[T_{\mathrm{S}}\right]$, and what is left of the harvested residues.

\section{Results and discussion}

This section presents and discusses the main outcomes of the co-evolution of local systems towards, primarily, intensification of management, as well as privatization of common grazing resources, and their combined effect with respect to ecological (soil fertility, feeds) and social (food security, income, labour) indicators (Table 4). Section 4 will wrap up and outline some management and policy implications of the revealed trends.

\subsection{Soil fertility (Fig. 3)}

The organic matter and nutrient status of the land managed by 'camp' farms, well endowed in livestock, is higher than of the 'village' farms in current systems, where resources are shared. With increasing intensification, $\mathrm{N}$ status generally declines, OM status either slightly declines (on S1, S4 soils) or improves (on S3 soils), while $\mathrm{P}$ status is mostly unaffected or slightly improves, depending on farm and soil type.

Intensification often prevents the organic matter balance of soils of the "village poor' farms from turning negative, or even leads to improvement of their fertility 
Table 4

Summary of scenario results

\begin{tabular}{|c|c|c|c|c|}
\hline & Indicator & Current systems & Intensification & Privatisation \\
\hline \multirow[t]{3}{*}{$\begin{array}{l}\text { Soil fertility } \\
\text { status (Fig. 3) }\end{array}$} & $\mathrm{N}$ balance & $\begin{array}{l}\text { Higher for 'camp' } \\
\text { farms than for 'village' } \\
\text { farms. }\end{array}$ & $\begin{array}{l}\text { Generally declining. *Generally, negative as } \\
>40 \% \text { land is cropped. }\end{array}$ & $\begin{array}{l}\text { Generally, decline on 'camp' farms; } \\
\text { stable or improve on VP, VR farms }\end{array}$ \\
\hline & P balance & & $\begin{array}{l}\text { Generally, unaffected or slightly improving. } \\
* \text { Negative on S1 if }>40 \% \text { land cropped, positive } \\
\text { on S3, S4 (except for VR). }\end{array}$ & \\
\hline & Soil OM balance & & $\begin{array}{l}\text { Generally slightly declining or improving. } \\
\text { Remain mostly positive for VP on S3, S4. }\end{array}$ & \\
\hline \multicolumn{2}{|c|}{ Forage availability status (Table 5 ) } & $\begin{array}{l}\text { Animal production of } \\
\text { VM farms is most } \\
\text { limited. }\end{array}$ & $\begin{array}{l}\text { Improving for all farms as more crop residues } \\
\text { and legumes become available (except for CR, } \\
\text { which need further transhumance). }\end{array}$ & $\begin{array}{l}\text { Differs between farms: VR use more } \\
\text { residues, CP, CR use more pastures. }\end{array}$ \\
\hline \multirow[t]{2}{*}{$\begin{array}{l}\text { Food security } \\
\text { status }\end{array}$} & Cereal grain (Table 6) & $\begin{array}{l}\text { Consumption } \\
\text { requirements met by all } \\
\text { farms except VP. }\end{array}$ & $\begin{array}{l}\text { Crop production increases for all farms; } \\
\text { consumption requirements met by all farms, } \\
\text { including VP. }\end{array}$ & $\begin{array}{l}\text { Crop production increases most } \\
\text { markedly for 'camp' farms, less for } \\
\text { VP; VP, though, can meet con- } \\
\text { sumption requirements. }\end{array}$ \\
\hline & Meat, Milk (Table 7) & $\begin{array}{l}\text { Consumption require- } \\
\text { ments not met by VP, } \\
\text { VR farms. }\end{array}$ & $\begin{array}{l}\text { Increase in p.c. meat production; relative } \\
\text { decline of milk production. Sustenance levels } \\
\text { still not met by VP, VR farms. }\end{array}$ & $\begin{array}{l}\text { Increase in p.c. meat production, } \\
\text { relative decline of milk production. } \\
\text { Sustenance levels still not met by } \\
\text { VP, VR farms. }\end{array}$ \\
\hline \multirow[t]{2}{*}{$\begin{array}{l}\text { Social } \\
\text { indicators } \\
\text { status }\end{array}$} & Income/cap (Table 8) & $\begin{array}{l}\text { Above sustenance for } \\
\text { all farms except VP. }\end{array}$ & $\begin{array}{l}\text { Increase for all farms. }{ }^{*} \text { With expanding area } \\
\text { cropped, VP still cannot meet sustenance levels. }\end{array}$ & $\begin{array}{l}\text { Decline for VP, VR. For VM, CP, } \\
\mathrm{CR} \text {, increase if current management } \\
\text { prevails, decrease if intensification } \\
\text { prevails. }\end{array}$ \\
\hline & $\begin{array}{l}\text { Labour availability } \\
\text { (Table 9) }\end{array}$ & $\begin{array}{l}\text { Shortages for all farms } \\
\text { in 'mid-wet' season, for } \\
\text { VR in 'late wet', 'early } \\
\text { dry' season. }\end{array}$ & $\begin{array}{l}\text { Improving particularly in 'mid-late wet' } \\
\text { season, worsens in 'mid-late dry', 'early wet' } \\
\text { season. VR cannot overcome seasonal labour } \\
\text { constraints. }\end{array}$ & $\begin{array}{l}\text { Shortages exacerbated at cropping } \\
\text { times, particularly for VP, VR. Only } \\
\text { CP farms are unaffected. }\end{array}$ \\
\hline
\end{tabular}

Farm types: $\mathrm{CP}=$ 'camp poor', $\mathrm{CR}=$ 'camp rich', $\mathrm{VM}=$ 'village managers', $\mathrm{VP}=$ 'village poor', $\mathrm{VR}=$ 'village rich'.

Soil Types: S1 = marginal silty, S2 = unsuitable for cropping, S3 = fair-to-poor sandy, S4 = fertile soils. 
At different levels of relative area cropped ( 25 to $90 \%$ ) and of intensification (current, more intensive) in systems where resources are shared, and their change after co-evolution to privatisation of resource use.

\begin{tabular}{|c|c|c|c|c|c|c|c|c|c|c|c|c|c|c|c|c|c|c|c|}
\hline & \multirow{4}{*}{\begin{tabular}{|r} 
Management Options $>$ \\
Balance of: \\
On soils:
\end{tabular}} & \multicolumn{18}{|c|}{ Shared Resource System (SRS) } \\
\hline & & & \multicolumn{8}{|c|}{ Current } & \multicolumn{9}{|c|}{ More intensive } \\
\hline \multirow{3}{*}{$\begin{array}{l}\text { Cropping } \\
\text { intensity }\end{array}$} & & \multirow{2}{*}{\multicolumn{3}{|c|}{ OM }} & \multicolumn{3}{|c|}{$\bar{N}$} & \multirow{2}{*}{\multicolumn{3}{|c|}{$\begin{array}{l}P \\
3\end{array}$}} & \multicolumn{3}{|c|}{$\overline{\mathrm{OM}}$} & \multicolumn{3}{|c|}{$\overline{\mathrm{N}}$} & \multicolumn{3}{|c|}{$\bar{P}$} \\
\hline & & & & 4 & 1 & 3 & 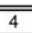 & & & 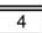 & 1 & 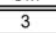 & 4 & 1 & 3 & 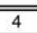 & 1 & 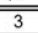 & 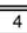 \\
\hline & Farm Types & & & & & & & & & & & & & & & & & & \\
\hline \multirow{5}{*}{$25 \%$} & 'camp poor' & & & & & & & & & & & & & & & & & & \\
\hline & 'camp rich' & & & & & & & & & & & & & & & & & & \\
\hline & 'village managers' & & & & & & & & & & & & & & & & & & \\
\hline & 'village poor' & & & & & & & & & & & & & & 4 & & - & 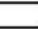 & \\
\hline & 'village rich' & & & & & & & & & & & & & & & & & & \\
\hline \multirow{4}{*}{$\begin{array}{l}40 \% \\
\text { Bani }\end{array}$} & 'camp poor' & & & & & & & & & & & & & & & & & & \\
\hline & 'camp rich' & & & & & & & & & & & & & & 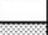 & & & & \\
\hline & $\begin{array}{l}\text { Vullage poor' } \\
\text { 'vills }\end{array}$ & & & & & & & & & & & & & & : & & & & \\
\hline & 'village rich' & & & & & & & & & & & & & & & & & & \\
\hline \multirow{5}{*}{$\begin{array}{l}50 \% \\
\text { Tigo }\end{array}$} & 'camp poor' & & & $\cdots$ & & Hi & & & & & & & :. & & & & - & & \\
\hline & 'camp rich' & & & $\cdots$ & - & $\cdots$ & -. & & & & & $\cdots$ & $\cdots$ & - & $\cdots$ & & - & & \\
\hline & 'village managers' & & & & & +3 & & & & & & $\cdots$ & & & $=0$ & + & (3) & 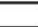 & \\
\hline & 'village poor' & (1) & & + & & \# & T & & + & 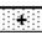 & \# & $\cdots$ & & & 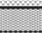 & & & & \\
\hline & 'village rich' & +1 & +m+ & + & & + & 7 & & + & +1 & \# & & + & & 7 & + & 戠 & $t$ & +4 \\
\hline \multirow{5}{*}{$\begin{array}{c}65 \% \\
\text { Kodey }\end{array}$} & 'camp poor' & & - & & & & & & & & & का & & & & & 盈 & & \\
\hline & 'camp rich' & - & $\cdot$ & $\cdots$ & & ti & $=$ & & & & - & $\cdots$ & $\cdots$ & & एक & & - & & \\
\hline & 'village managers' & & & & & + & & & & & + & $\cdots$ & & & $\because$ & & & & \\
\hline & 'village poor' & & +t+ & & & & & & + & + & कt & +7 & $\cdots$ & & 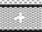 & & 藏 & & \\
\hline & $\begin{array}{l}\text { 'village rich' } \\
\end{array}$ & & +世+ & & & & & & + & $t$ & wh & 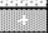 & & & + & & 8 & + & +4 \\
\hline \multirow{5}{*}{$90 \%$} & 'camp poor' & $t$ & 6 & & & & & & & & & $\cdots$ & & & $=$ & & $=$ & & \\
\hline & 'camp rich' & & $\cdots$ & & & & & & & & & $\cdots$ & & 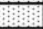 & Hi: & & 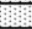 & & \\
\hline & 'village managers' & $t$ & & & & & & & & & & $\cdots$ & & & & & & & \\
\hline & 'village poor' & \pm & + & & & & & & + & 4 & & ++ & $\cdots$ & & + & & & +1 & \\
\hline & 'village rich' & t & ++ & & & + & & & + & $t$ & & & & & & & & & + \\
\hline
\end{tabular}

Legend:
Nutrients:
Soil Types:
$\mathrm{OM}=$ Organic Matter, $\mathrm{N}=$ Nitrogen, $\mathrm{P}=$ Phosphorus;
Relative area cropped:
$1=$ marginal silty, 3 = fair-to-poor sandy, 4 = fertile soils; $25 \%-90 \%$

Empty (white) cells represent positive balances; shaded cells represent different degrees of negative balances. Symbol (+) in the cells indicate whether the nutrient status would become positive (or less negative) with privatization, when compared with local current with shared resources, and $(-)$ whether would become negative (or even more negative).

\begin{tabular}{|c|c|c|c|}
\hline $\mathrm{kg} / \mathrm{ha}$ & \multicolumn{1}{|c|}{ OM } & \multicolumn{1}{c|}{$\mathrm{N}$} & \multicolumn{1}{c|}{$\mathrm{P}$} \\
\hline & less than -1000 & less than -50 & less than -10 \\
\hline$-1000 /-500$ & $-50 /-25$ & $-10 /-5$ \\
\hline$-500 /-250$ & $-25 /-12.5$ & $-5 /-2.5$ \\
\hline$-250 / 0$ & $-12.5 / 0$ & $-2.5 / 0$ \\
\hline & Positive nutrient balance \\
\hline
\end{tabular}

Fig. 3. Soil organic matter and nutrient balances.

status. Phosphorus balances are generally negative, regardless of management intensity on marginal (S1) soils when more than $40 \%$ of the land is cropped, and positive on the other soils under intensified management, except when managed by the 'village rich' farms. Nitrogen balances are negative in most cases - both under current and more intensive management - when the relative area cropped exceeds $40 \%$, with the deficits least pronounced on the $\mathrm{S} 1$ soils and for the 'camp rich' farms.

Privatization results in a decline in soil fertility status that affects the land managed by the 'camp' farms relatively stronger than that of the 'village' farms. The reason might be that, particularly under current management, the former profit less from the benefits associated with the sharing of open-access grazing resources and the latter benefit relatively more from the recycling of organic material produced 
on the land they manage. Privatization, in fact, restricts crop-livestock interaction to within the farm; this entails loss of opportunities, due to mismatches in the balances between crop and livestock activities within the farm, unless institutional pathways exist for compensation, such as manuring or grazing contracts, or for selling crop residues. Under privatization, managing livestock appears insufficient to prevent declining soil organic matter and nutrient contents, especially when more than $40 \%$ of the land is cropped. The benefits from manure produced by livestock are in fact limited by the restrictions on access to grazing resources, particularly for the 'camp rich' and 'village managers' farms with relatively large herds. The 'poor' farms residing in 'villages', instead, should normally be able to maintain soil fertility on their land.

\subsection{Feed availability}

Under current management, forage shortages limit livestock production of the 'village managers' farms. Intensification, leading to increased availability of crop residues and a higher share of legume crops in the rotation, results in higher overall feed availability and animal production capacity for all but the 'camp rich' farms. As a result, this category will - in the long term - become more and more often dependent on transhumance (see Table 5).

With increasing intensification, sorghum is partially replaced on the more fertile soils by the millet-cowpea intercrop, to the point that - at higher relative areas cropped - it is only cultivated to a significant extent by the 'village rich'. While most farms increase their relative share of leguminous crops (cowpea, peanut), of which the haulms are available as (high quality) animal feed, the non-harvested fraction of sorghum stalks, of better feeding value than millet residues, are increasingly left to be grazed in the field.

With increasing privatisation, animal feed availability differentially changes among farms; for instance, the 'village rich' farms increasingly rely on crop residues, and the 'camp' farms on pastures.

\subsection{Food production and consumption}

Most farms meet their annual cereal consumption requirements already under current management conditions in the current shared resource system, with the exception of the 'village poor' ( $225 \mathrm{~kg}$, versus an estimated requirement of $250 \mathrm{~kg}$ for settled farmers), while the 'camp poor' are at the edge $(217 \mathrm{~kg}$, versus an esti-

Table 5

Change in forage availability (DM/TLU) associated with intensification

\begin{tabular}{lcl}
\hline Farm types & Current management (kg dry matter) & Intensification (\% change) \\
\hline 'Camp poor' & 3346 & +15 to +30 \\
'Camp rich' & 4118 & -10 \\
'Village managers' & 1980 & +55 to +70 \\
'Village poor' & 23126 & +4 \\
'Village rich' & 8464 & +342 \\
\hline
\end{tabular}


mated requirement of $200 \mathrm{~kg}$ for nomads). With increasing intensification (Table 6), crop production can increase by between $75 \%$ and $91 \%$, depending on farm type. Cowpea production increases are most sizeable; increases in sorghum grain production are largest for the 'camp rich' and 'village managers' farms, while millet grain production is among the highest for the 'village poor'. Under privatisation the 'camp' farms show the highest increases in crop production $(+82 \%)$, whereas the 'village poor' experience a moderate but evident reduction in sorghum production and can increase total production by only $15 \%$, hence can only minimally improve food security.

Despite noticeable increases in meat production associated with intensification (Table 7), on-farm animal production (meat and milk) per capita (p.c.) of the "village

Table 6

Change in crop production with intensification (INT) and privatization (PRIV)

\begin{tabular}{|c|c|c|c|c|c|c|c|c|}
\hline \multirow[t]{2}{*}{ Farm types } & \multicolumn{2}{|c|}{ Cowpea } & \multicolumn{2}{|c|}{ Sorghum } & \multicolumn{2}{|c|}{ Millet } & \multicolumn{2}{|c|}{$\begin{array}{l}\text { Total crop } \\
\text { production change }\end{array}$} \\
\hline & INT & PRIV & INT & PRIV & INT & PRIV & INT & PRIV \\
\hline 'Camp poor' & +++ & +++ & + & + & ++ & ++ & $87 \%$ & $82 \%$ \\
\hline 'Camp rich' & +++ & +++ & ++ & + & + & ++ & $91 \%$ & $82 \%$ \\
\hline 'Village managers' & +++ & +++ & ++ & + & + & ++ & $90 \%$ & $74 \%$ \\
\hline 'Village poor' & +++ & +++ & + & - & ++ & ++ & $75 \%$ & $15 \%$ \\
\hline 'Village rich' & +++ & +++ & + & + & ++ & + & $87 \%$ & $59 \%$ \\
\hline
\end{tabular}

Legend: $+=$ increase, $++=$ strong increase, $+++=$ very strong increase, $-=$ decrease.

Table 7

Meat and milk production and availability, and predicted change as a result of (I) intensification of management and (II) privatisation of resource use

\begin{tabular}{|c|c|c|c|c|}
\hline \multirow[t]{2}{*}{ Current management } & \multicolumn{2}{|l|}{ Meat } & \multicolumn{2}{|l|}{ Milk } \\
\hline & $\left(\mathrm{kg} \mathrm{y}^{-1}\right)$ & $\left(\mathrm{kg} \mathrm{y}^{-1} \mathrm{aceq}^{-1}\right)^{\mathrm{a}}$ & $\left(\mathrm{kg} \mathrm{y}^{-1}\right)$ & $\left(\mathrm{kg} \mathrm{y}^{-1} \mathrm{aceq}^{-1}\right)^{\mathrm{a}}$ \\
\hline Camp poor & 365.6 & 53.6 & 600.6 & 88.1 \\
\hline Camp rich & 1038.0 & 169.1 & 1531 & 249.3 \\
\hline Village managers & 687.3 & 70.1 & 930.6 & 95.0 \\
\hline Village poor & 74.7 & 13.0 & 106.1 & 18.4 \\
\hline Village rich & 57.4 & 10.9 & 73.8 & 14.0 \\
\hline \multicolumn{5}{|l|}{$\begin{array}{l}\text { (I) Total change with intensifica- } \\
\text { tion }\end{array}$} \\
\hline Camp poor & \multicolumn{2}{|l|}{$+7 \%$} & \multicolumn{2}{|l|}{$-17 \%$} \\
\hline Camp rich & \multicolumn{2}{|l|}{$+2.4 \%$} & \multicolumn{2}{|l|}{$\mathrm{b}$} \\
\hline Village managers & \multicolumn{2}{|l|}{$\mathrm{b}$} & \multicolumn{2}{|l|}{$\mathrm{b}$} \\
\hline Village poor & \multicolumn{2}{|l|}{$+3 \%$} & \multicolumn{2}{|l|}{$-15 \%$} \\
\hline $\begin{array}{l}\text { Village rich } \\
\text { (II) Range of expected change } \\
\text { with privatisation }\end{array}$ & \multicolumn{2}{|l|}{$+4.5 \%$} & \multicolumn{2}{|l|}{$-17 \%$} \\
\hline All households & \multicolumn{2}{|l|}{+4 to $+8 \%$} & \multicolumn{2}{|l|}{-6 to $-19 \%$} \\
\hline
\end{tabular}

${ }^{\mathrm{a}} \mathrm{kg} /$ year/adult consumer equivalent (aceq).

${ }^{\mathrm{b}}$ No expected change. 
poor' and 'village rich' households never meets their consumption requirements. Meat production increases also under privatisation, by $4-8 \%$, depending on farm type. Goat meat production contributes most to this increase. Despite this increase, however, the consumption requirements of most 'village' households cannot be met, with the exception of those of the 'village managers'. Under privatisation, similarly to what happens with increasing intensification, relative milk production decreases (6-19\%) particularly for farms having smaller herds. This decline appears to be linked to changes in species composition of the herd, to a specialization in favour of market-oriented meat production, and to the concentration of animal production at the larger livestock farms. This is, however, modest in absolute terms, since on those farms animal production is relatively limited.

\subsection{Income and labour}

Agriculture, under current forms of management, is an uncertain activity for the 'village poor' farms as their income is always below the minimum levels required for subsistence (Table 8). This does not change when relative areas cropped expand. Under intensification, on the other hand, all farms achieve higher incomes p.c. than required for subsistence. Under privatisation, however, incomes of the livestock-scarce 'village poor' and 'village rich' farms decline, regardless of the intensity of management. Incomes on the 'village managers' and livestock-endowed 'camp' farms, instead, increase under current management, but decline if privatisation is combined with intensification.

Table 8

Changes in farm household incomes from shared resource systems to privatization

\begin{tabular}{|c|c|c|c|c|c|c|c|}
\hline \multirow{2}{*}{$\begin{array}{l}\text { Farm types } \\
\text { Study sites: }\end{array}$} & \multicolumn{6}{|c|}{ Relative area cropped } & \multirow{2}{*}{$\begin{array}{l}\text { Change with } \\
\text { privatisation }\end{array}$} \\
\hline & $25 \%$ & $\begin{array}{l}40 \% \\
\text { Bani }\end{array}$ & $\begin{array}{l}50 \% \\
\text { Tigo }\end{array}$ & $\begin{array}{l}65 \% \\
\text { Kodey }\end{array}$ & $90 \%$ & $>90 \%$ & \\
\hline \multicolumn{8}{|l|}{ Current management } \\
\hline 'Camp poor' & 86437 & 100928 & 103984 & 108349 & 111754 & 112712 & +3.5 \\
\hline 'Camp rich' & 199462 & 233048 & 240173 & 250435 & 258554 & 255294 & +6.9 \\
\hline 'Village managers' & 109562 & 130456 & 134885 & 141229 & 146317 & 147584 & +2.4 \\
\hline 'Village poor' & 43942 & 52227 & 53985 & 56496 & 58504 & 58991 & -9.7 \\
\hline 'Village rich' & 94375 & 110706 & 114153 & 119102 & 123061 & 124065 & -19.8 \\
\hline \multicolumn{8}{|c|}{ More intensive management } \\
\hline 'Camp poor' & 126847 & 140886 & 143858 & 148393 & 151885 & 153204 & -6.2 \\
\hline 'Camp rich' & 255568 & 288427 & 295773 & 305951 & 314093 & 316634 & -1.6 \\
\hline 'Village managers' & 179539 & 203930 & 208365 & 214703 & 219772 & 221065 & -2.6 \\
\hline 'Village poor' & 89645 & 97945 & 99714 & 102225 & 104249 & 106450 & -14.0 \\
\hline 'Village rich' & 214634 & 230965 & 234429 & 239378 & 243337 & 245581 & -20.6 \\
\hline
\end{tabular}

Annual incomes p.c. (CFA) at different relative areas cropped, intensification of management, and change to privatisation. 
Table 9

Current seasonal labor balances, change with intensification, and privatisation

\begin{tabular}{|c|c|c|c|c|c|c|c|}
\hline \multicolumn{3}{|c|}{ Seasons } & \multirow{2}{*}{$\begin{array}{c}\text { Camp poor } \\
\underline{0.32}\end{array}$} & \multirow{2}{*}{$\begin{array}{l}\text { Camp rich } \\
\underline{0.04}\end{array}$} & \multirow{2}{*}{$\begin{array}{l}\begin{array}{l}\text { Village } \\
\text { managers }\end{array} \\
-0.01\end{array}$} & \multirow{2}{*}{$\begin{array}{l}\begin{array}{l}\text { Village } \\
\text { poor }\end{array} \\
0.22\end{array}$} & \multirow{2}{*}{$\begin{array}{l}\text { Village rich } \\
-0.12\end{array}$} \\
\hline Dry & Early & (Cur)* & & & & & \\
\hline & & (Int) & $+\overline{0.06}$ & $+\overline{0.06}$ & $\overline{+0.05}$ & $+\overline{0.05}$ & $\overline{+0.04}$ \\
\hline & & (Priv) & +0.01 & -0.12 & -0.14 & -0.08 & -0.07 \\
\hline & Mid-late & (Cur)* & $\underline{0.57}$ & $\underline{0.29}$ & $\underline{0.25}$ & $\underline{0.49}$ & $\underline{0.15}$ \\
\hline & & (Int) & $-\overline{0.10}$ & $-\overline{0.12}$ & $-\overline{0.12}$ & $-\overline{0.11}$ & $-\overline{0.12}$ \\
\hline & & (Priv) & - & +0.02 & +0.01 & +0.02 & +0.05 \\
\hline \multirow[t]{9}{*}{ Wet } & Early & (Cur)* & $\underline{0.54}$ & $\underline{0.26}$ & 0.22 & 0.44 & $\underline{0.11}$ \\
\hline & & (Int) & $-\overline{0.12}$ & $-\overline{0.13}$ & $-\overline{0.11}$ & $-\overline{0.10}$ & $-\overline{0.12}$ \\
\hline & & (Priv) & +0.02 & +0.03 & -0.01 & +0.01 & +0.03 \\
\hline & Mid & (Cur)* & -0.84 & -1.11 & -1.16 & -0.93 & -1.27 \\
\hline & & (Int) & $\overline{+0.60}$ & $\overline{+0.59}$ & $\overline{+0.59}$ & $\overline{+0.60}$ & $\overline{+0.60}$ \\
\hline & & (Priv) & - & +0.01 & - & -0.16 & -0.25 \\
\hline & Late & (Cur)* & $\underline{0.20}$ & -0.08 & -0.13 & $\underline{0.10}$ & -0.23 \\
\hline & & (Int) & $+\overline{0.14}$ & $\overline{+0.14}$ & $\overline{+0.15}$ & $+\overline{0.14}$ & +0.14 \\
\hline & & (Priv) & - & - & - & -0.04 & -0.07 \\
\hline
\end{tabular}

Legend: Seasonal labor balance *(person-days/year/ha) with (Cur) current management; (Int) change of balance after intensification, and (Priv) change after privatization of current shared resource systems.

Under current management, considerable labour shortages occur that affect the production of all farms during the 'mid-wet' season, and for the 'village rich' farms in particular, during the 'late wet' and, less markedly, the 'early dry' seasons (Table 9). Under intensification, labour shortages markedly decline, particularly during the 'mid-wet' season and - less markedly - during the 'late wet' and 'early dry' seasons, while they increase during the rest of the year. This is associated with a more optimal seasonal allocation of labour and a more balanced labour distribution between crops and livestock within the farm. These changes are linked to a more conveniently scheduled out-migration of labourers, that allows them to be present in the study area during peak cropping times and seek wage-labour, outside agriculture in the capital city or in neighbouring nations, outside the cropping season. Farm households interact with each other and evolve over time. Poorer households or those that cannot satisfy consumption requirements or with members unable to find local waged employment, may migrate or their working members may become part of other households that have increased in size or wealth, while larger ones may fragment into smaller ones.

Increases in labour availability for the labour-scarce 'village rich' farms - which have the highest labour requirements, as they have the largest area of cropland p.c. - and, relatively less, for the 'village poor', are not sufficient to avoid labour shortages during the critical weeding and harvesting times. Seasonal labour deficits are further exacerbated by privatisation during the 'mid-late wet' to 'early dry' seasons, particularly for the 'village poor' and 'village rich' farms, while the labour availability of the 'camp poor' farms is unaffected. 


\subsection{Modelling results vis-à-vis the real world}

Although validating explorative studies is deemed inappropriate, due to large discrepancies between assumptions for the future and actual conditions (Kruseman, 2000), a number of key outputs is being compared to real-world developments. For instance, the soil nutrient balances in our study generally match with those reported for comparable systems and scales in the Sahel (Savadogo, 2000; Van der Pol, 1992; Stoorvogel and Smaling, 1990), but are generally more optimistic than soil nutrient balances presented in other studies (i.e. Barbier and Hazell, 2000; Struif Bontkes, 1999; Sissoko, 1998). Detailed comparisons are difficult, because of differences in agro-ecological conditions for some studies, or of the dynamic or long-term nature of their approach. To put the results in perspective, scenario outputs describing prospected changes (i.e. intensification) at the study site have been compared to actual conditions at other locations in the Sahel, which can be viewed to represent a further level of co-evolution of current systems. Income levels, in particular, match closely those from survey data for similar areas in Niger's Sahel.

\section{Conclusions}

The study has revealed differential impacts of the anticipated co-evolution of farming systems in south-western Niger towards adoption of more intensive forms of management, privatisation of commonly managed grazing resources, and their combination.

In present systems, farm households that manage substantial numbers of livestock can take advantage of the use of communal grazing resources thanks to animal mobility, hence they benefit from the integrated management of crops and livestock (Achard and Banoin, 2003). Their use of local resources is facilitated by the existence of a complex web of arrangements between local institutions and stakeholders from different ethnic and social groups. Severe income and food insecurity, as well as limitations in productive capacity, affect mainly the 'village poor' farms.

Increasing intensification may impact differentially on soil fertility, and the related food and economic security of different farms. Most remarkable is probably that nitrogen balances are likely to deteriorate in most cases as a result of management intensification, suggesting that nitrogen may be the major external nutrient input that will be needed to sustain the process of agricultural intensification. This finding, that may have several policy and management implications, needs to be interpreted in the light of the complex interactions and dynamics of soil nutrients and of the long-term character of improvements in soil organic matter and nutrient contents. These characteristics, as well as ways to account for other nutrient flows linked to hydrological and atmospheric flows, and soil erosion, could not be fully taken into account in the TCG data generation and mathematical modelling equations and constitute aspects of complex systems modelling that need further 
research. Therefore, the results of this modelling exercise are particularly meaningful for a limited time horizon.

Another overarching outcome is that intensification will generally lead to increased agricultural production and improved food security and income conditions for the population in the area. However, that will not be sufficient to move the currently most affected group - the 'village poor', which account for $40 \%$ of the households and people - away from serious vulnerability threats to their livelihoods. This group would still need to be the priority objective and focus of development action aimed at relieving them from malnutrition in terms of animal protein, and of persistently low incomes.

Intensification, though leading to reduced labour shortages at critical times in the cropping cycle, does not fully remove the constraint of seasonal labour shortage, particularly not for the 'village rich' farms. Furthermore, expansion of the seasonal national and trans-national out-migration towards cities and better salaries outside agriculture may exacerbate the already low on-farm productive capacity of particularly the 'poorer' farm households.

The study suggests that privatisation and particularly intensification will boost crop production. This is associated with expected increases in labour demand for cropping. Most households will however face increased difficulties in having sufficient labour available to meet this demand, especially during the peak labour periods in the cropping season. Labour shortages during the critical cropping periods could negatively impact on the productive capacity of particularly the 'village poor' farms, which are likely to face the highest future risk of economic and nutritional insecurity. Intensification will lead to higher incomes. The same will occur with privatisation, while maintaining current forms of management, limited to the livestock-endowed farms. If instead privatization is associated with intensification, all farms are faced with lower incomes.

Finally, we make a few methodological remarks, dealing with the type of issues at which further research should focus:

- It is virtually impossible to capture nutrient flows linked to the mobility of animals by modelling only the farm level. If this would be the case, results of the scenarios would show that pastoral groups capture far less benefits than the poorly-livestock endowed 'land-owners'. The current approach, therefore, provides a way to explicitly model effects of the shared use of common open-access resources, with access proportional to the number of managed livestock. This approach thus helps in avoiding the risk of underestimating or misallocating the benefits of managing livestock derived from grazing crop residues and releasing manure on arable fields. Its success, however, depends on the availability of robust biophysical and land use data at the farm as well as at the community levels.

- Since in local social systems different (types of) households strongly interact, further improvements in such bio-economic approaches should combine the farm and community scales (Kruseman, 2000). That should allow for explicitly simulating farm dynamics (Struif Bontkes, 1999), and take into account the existence of labour contracts among households and the flows of labour, resources and money within the system. 


\section{Acknowledgements}

Thanks are due to: Bologna University, Italy, for its financial support; International Livestock Research Institute (ILRI), Niger, for providing data and expert knowledge; and Wageningen University, The Netherlands, for its scientific and logistic support.

\section{Appendix A. Nomenclature of selected variables and parameters}

Sets

a cropping activities

c crops/mi, so, ni, fa/

ct(c) crops without fallow/mi, so, ni/

e pasture types/w, y/

f SOM and nutrient types/SOM, N, $\mathrm{P}, \mathrm{K} /$

t animals/ca, sh, go/

$\mathrm{k}$ equipment types/ct, ox, do/

$\mathrm{m}$ animal forage rations (combinations)

$\mathrm{p} \quad$ labour periods/p1*p5/

q digestible organic matter (OM)

bq(q) high quality digestible OM

$r \quad$ feeding strategy/r $1 *^{r} 4 /$

s soils/s $1 *$ s $4 /$ (different levels of relative cropped area)

(millet, sorghum, cowpea, fallow)

(millet, sorghum, cowpea)

(type available in the wet season, and in the whole year)

(soil organic matter, nitrogen, phosphorus, potassium)

(cattle, sheep, goat)

(carts, oxen, donkey)

'early dry', 'mid-late dry', 'early wet', 'mid-wet', 'late wet'

quality types

quality types

(different energy intake levels)

'S1' = silty, marginal for farming,

'S2' = unsuitable for farming

'S3' = sandy, fair to poor,

'S4' = fertile, vulnerable to erosion
Variables

UTIL

UCO

NETINC

$\mathrm{CROPINC}_{\mathrm{c}}$

LIVINC

OFLINC

TCROCOST

LIVCOST objective value

utility of consumption

net revenue

CFA

crop income

CFA

CFA

CFA

CFA

CFA 


\begin{tabular}{|c|c|c|}
\hline HLABCOST & hired labour costs & CFA \\
\hline CORINC & corrected income & CFA \\
\hline NANIMAL $_{t, r}$ & number of animals & TLU \\
\hline TRAC animal traction & TLU & \\
\hline LABDONK & donkeys & TLU \\
\hline LABOXEN & oxen & TLU \\
\hline $\mathrm{LABBAL}_{\mathrm{p}}$ & labour balance & aleq \\
\hline TLABREQ $_{p}$ & total labour requirement & aleq \\
\hline $\mathrm{OFL}_{\mathrm{p}}$ & off-farm labour & aleq \\
\hline HIRLAB $_{p}$ & hired labour & aleq \\
\hline LANDUSE $_{\mathrm{c}, \mathrm{s}, \mathrm{a}}$ & land use & ha \\
\hline PASTAVA $_{\mathrm{e}, \mathrm{s}}$ & pasture land availability & ha \\
\hline TOTRES $_{\mathrm{q}}$ & total residue production & $\mathrm{kg}$ \\
\hline RESCRTRA $_{\mathrm{bq}, \mathrm{ct}}$ & $\begin{array}{l}\text { residue production during transhumance } \\
\text { time }\end{array}$ & $\mathrm{kg}$ \\
\hline MANURE & manure left by animals & $\mathrm{kg}$ \\
\hline NUTBAL $_{\mathrm{s}, \mathrm{f}}$ & nutrient balance & $\mathrm{kg} / \mathrm{ha}$ \\
\hline NUTAVA $_{\mathrm{s}, \mathrm{f}}$ & nutrient availability & $\mathrm{kg} / \mathrm{ha}$ \\
\hline DOMBAL $_{\mathrm{q}}$ & digestible organic matter (DOM) balance & $\mathrm{kg}$ \\
\hline DOMAVA $_{q}$ & DOM availability & $\mathrm{kg}$ \\
\hline DOMREQ $_{\mathrm{m}, \mathrm{r}}$ & DOM requirements & $\mathrm{kg}$ \\
\hline DOMBATRAN & DOM balance during transhumance time & $\mathrm{kg}$ \\
\hline DOMAVTRA $_{\mathrm{bq}}$ & $\begin{array}{l}\text { DOM availability during transhumance } \\
\text { time }\end{array}$ & $\mathrm{kg}$ \\
\hline
\end{tabular}

Parameters
$\Phi_{1}$
$\Phi_{2}$
$\alpha$
$\delta$

maxconut

maxcorin

$\operatorname{pan}_{\mathrm{t}, \mathrm{r}}$

pdonk

poxen

famlab $_{\mathrm{p}}$

labcrreq $\mathrm{p}, \mathrm{c}, \mathrm{s}, \mathrm{a}_{\mathrm{a}}$ labanreq $q_{p, t, r}$

$\operatorname{anlabav}_{\mathrm{k}}$ translvy $y_{t}$ hired labour costs

CFA

CFA

TLU

TLU

TLU

aleq

aleq

lec

ha

$\mathrm{kg}$

$\mathrm{kg}$

g/ha

$\mathrm{kg}$

kg

$\mathrm{kg}$ time 
Unit

Fractions of the average year of key seasonal animal feeding and periods:

- $T_{\mathrm{S}} \quad$ last months before cropping

$(2 / 12) \quad$ months

(short transhumance to Southern pastures

- $T_{\mathrm{L}} \quad$ long transhumance to Northern pastures

$(4 / 12) \quad$ months

- $T_{\mathrm{R}} \quad$ first months after harvest time

months

(local animal mobility for residues)

Selected datasets originating from the ecological and socio-economic surveys generated through the TCG system:

\begin{tabular}{|c|c|c|}
\hline $\operatorname{ertava}_{\mathrm{ct}, \mathrm{s}, \mathrm{a}, \mathrm{f}}$ & external fertiliser available & Calculated with TCG \\
\hline nutreq $_{\mathrm{ct}, \mathrm{s}, \mathrm{a}, \mathrm{f}}$ & crop nutrient requirement & Calculated with TCG \\
\hline nutava $_{\mathrm{fa}^{\prime}, \mathrm{s}, \mathrm{a}, \mathrm{f}}$ & fallow nutrients available & Calculated with TCG \\
\hline astyield $_{\mathrm{e}, \mathrm{s}, \mathrm{q}}$ & pasture yields & Calculated with TCG \\
\hline presy $_{\mathrm{q}, \mathrm{ct}, \mathrm{s}, \mathrm{a}}$ & crop residue yield & Calculated with TCG \\
\hline domreq $_{\mathrm{q}, \mathrm{m}, \mathrm{r}}$ & $\begin{array}{l}\text { digestible organic matter } \\
\text { requirement (total) }\end{array}$ & Calculated with TCG \\
\hline $\operatorname{ligOM} M_{m, r}$ & indigestible OM & Calculated with TCG \\
\hline mreqan $_{t, r}$ & $\begin{array}{l}\text { digestible } \mathrm{OM} \text { requirement of } \\
\text { animals }\end{array}$ & Calculated with TCG \\
\hline $\operatorname{abreq}_{\mathrm{k}}$ & requirement for animal labour & Calculated with TCG \\
\hline
\end{tabular}

\section{References}

Achard, F., Banoin, M., 2003. Fallows, forage and nutrient transfers by livestock in Niger. Nutrient Cycling in Agroecosystems 65, 183-189.

AP3A Project, 2001. Le contexte de la vulnérabilité structurelle par système de production dans les pays du CILSS. AGRHYMET-OMM-Coopération Italienne, Niamey, Niger.

Barbier, B., Hazell, P., 2000. Implication of population growth and declining access to transhumant grazing area for the sustainability of agropastoral systems in the semi arid areas of Niger. In: McCarthy, N., Swallow, P., Kirk, M., Hazell, P. (Eds.), Property Rights, Risk and Livestock Development in Africa. International Food Policy Research Institute, Washington, pp. 371-395.

Boserup, E., 1983. Population and Technological Change: A Study of Long-term Trends. University of Chicago Press, Chicago, USA.

Breman, H., De Wit, C.T., 1983. Rangeland productivity and exploitation in the Sahel. Science 221, 13411347.

CIPEA/ILCA, 1994. Recueil statistique sur la production animale en Afrique, ILCA, Addis Ababa, Ethiopia.

De Ridder, N., Breman, H., Van Keulen, H., Stomph, T.J., 2004. Revisiting a 'cure against land hunger': soil fertility management and farming systems dynamics in the West African Sahel. Agricultural Systems 80, 109-131.

FAO statistics, FAOSTAT, 2000.

Hengsdijk, H., Van Ittersum, M.K., 2003. Formalizing agro-ecological engineering for future-oriented land use studies. European Journal of Agronomy 19, 549-562.

Hengsdijk, H., Quak, W., Bakker, E.J., Ketelaars, J.J.H.M., 1996. A Technical Coefficient Generator for land use activities in the Koutiala region of south Mali. DLV (Sustainable Land Use and Food 
Security) Report no. 5, CABO-DLO / Dept. Development Economics, Wageningen Agricultural University, Wageningen, The Netherlands.

Hiernaux, P., Fernández-Rivera, S., Schlecht, E., Turner, M.D., Williams, T.O., 1998a. Livestockmediated nutrient transfers in Sahelian agro-ecosystems. In: Renard, G., Neef, A., Becker, K., von Oppen, M. (Eds.), Soil Fertility Management in West African Land Use Systems. Margraf Verlag, Weikersheim, Germany, pp. 339-347.

Hiernaux, P., Fernández-Rivera, S., Schlecht, E., Turner, M.D., Williams, T.O., 1998b. Livestock management options in response to cropland expansion in the Sahel. In: Proceedings of an International Conference on Food, Lands and Livelihoods, BSAS/KARI, BSAS, Edinburgh, UK, pp. 12-13.

Kruseman, G., 2000. Bio-economic modeling for agricultural intensification. PhD Thesis, Wageningen University, Wageningen, The Netherlands.

Mortimore, M.J., Adams, W.M., 2001. Farmer adaptation, change and 'crisis' in the Sahel. Global Environmental Change 11, 49-57.

Norgaard, R.B., 1984. Co-evolutionary development potential. Land Economics 60, 160-173.

Pearce, D.W., Warford, J.J., 1993. World Without End. Economics, Environment, and Sustainable Development. Oxford University Press, New York, USA.

Penning De Vries, F.W.T., Dijtèye, M.A., 1991. La productivité des pâturages sahéliens. Uneétudes des sols, des végétations et de l'explotation de cette ressource naturelle. Agricultural Research Reports 918, Pudoc, Wageningen, The Netherlands.

Powell, J.M., Fernández-Rivera, S., Hiernaux, P., Turner, M.D., 1996. Nutrient cycling in integrated rangeland/cropland systems of the Sahel. Agricultural Systems 52, 143-170.

Raynaut, C., 2001. Society and nature in the Sahel: ecological diversity and social dynamics. Global Environmental Change 11, 9-18.

Ruttan, V.W., Hayami, Y., 1985. Induced innovation model of agricultural development. In: Staattz, J.M., Eicher, C.K. (Eds.), International Agricultural Development. The John Hopkins University Press, Baltimore, London, UK.

Savadogo, M., 2000. Crop residue management in relation to sustainable land use: a case study in Burkina Faso. Tropical Resource Management Paper No. 31, Wageningen, The Netherlands.

Schiere, J.B., Groenland, R., Vlug, A., van Keulen, H., in press. System thinking in agriculture: an overview. In: Rickert, K. (Ed.), Emerging Challenges for Farming Systems - Lessons from Australian and Dutch Agriculture. Rural Industries Research and Development Corporation, Kingston, Australia.

Schiere, J.B., Ibrahim, M.N.M., Van Keulen, H., 2002. The role of livestock for sustainability in mixed farming: criteria and scenario studies under varying resource allocation. Agriculture, Ecosystems and Environment 90, 139-153.

Schlecht, E., Hiernaux, P., Turner, M.D., 2001. Mobilité régionale du bétail : necessité et alternative? In: Tielkes, E., Schlecht, E., Hiernaux, P. (Eds.), Elevage et gestion de parcours au Sahel, implications pour le developpement. Verlag E. Grauer, Stuttgart, pp. 291-302.

Schlecht, E., Hiernaux, P., Achard, F., Turner, M.D., 2004. Livestock related nutrient budgets within village territories in western Niger. Nutrient Cycling in Agroecosystems 68, 199-211.

Sissoko, K., 1998. Et demain L'Agriculture? Options techniques et mesures politiques pour un developpement agricole durable en Afrique sub-saharienne: cas du Cercle de Koutiala en zone sud du Mali. Tropical Resource Management Paper No. 23, Wageningen, The Netherlands.

Slingerland, M., 2000. Mixed farming: Scope and constraints in West African savannah. Tropical Resource Management Paper No. 34, Wageningen, The Netherlands.

Stoorvogel, J.J., Smaling, E.M.A., 1990. Assessment of soil nutrient depletion in sub-Saharan Africa: 1983-2000. Report 28, Winand Staring Centre, Wageningen, The Netherlands.

Struif Bontkes, T., 1999. Modelling the dynamics of agricultural development: a process approach; the case of Koutiala (Mali). Tropical Resources Management Paper No. 25, Wageningen, The Netherlands.

Thébaud, B., Batterbury, S., 2001. Sahel pastoralists: opportunism, struggle, conflict and negotiation. A case study from eastern Niger. Global Environmental Change 11, 69-78. 
Turner, M., 1995. The sustainability of rangeland to cropland nutrient transfer in semi-arid West Africa: Ecological and social dimensions neglected in the debate. In: Livestock and Sustainable Nutrient Cycling in Mixed Farming Systems of Sub-Saharan AfricaPowell, J.M., Fernández-Rivera, S., Williams, T.O., Renard, C. (Eds.), Technical Papers, vol. II. ILCA, Addis Ababa, pp. 435-452.

Turner, M.D., Hiernaux, P., 2002. The use of herders' accounts to map livestock activities across agropastoral landscapes in Semi-Arid Africa. Landscape Ecology 17, 367-385.

Van der Pol, F., 1992. Soil Mining: An Unseen Contributor to Farm Income in Southern Mali. Bulletin of the Royal Tropical Institute, No. 325, Amsterdam, the Netherlands. 